\title{
Anoctamin 1 and c-Kit immunohistochemical study of interstitial cells of Cajal in the muscularis externa of human gastrointestinal tract
}

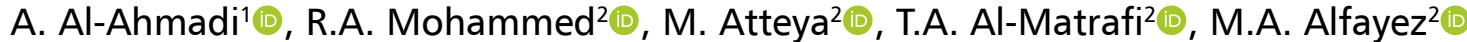 \\ 'Department of Chemistry, College of Science, King Abdulaziz University, Jeddah, Saudi Arabia \\ ${ }^{2}$ Department of Anatomy, College of Medicine, King Saud University, Riyadh, Saudi Arabia
}

[Received: 24 November 2021; Accepted: 20 December 2021; Early publication date: 31 December 2021]

Background: Interstitial cells of Cajal (ICC) are widely distributed in human gastrointestinal (GI) tract, especially in the layer of muscularis externa between neurons and smooth muscles. They play a very important role of coordination of GI tract motility. The aims of this research were to study the morphology and distribution of ICC in the muscularis externa of the GI tract, using immunohistochemistry staining methods, to determine the distribution of immune reactivity of anoctamin 1 (Ano 1) compared with c-Kit, and to determine if Ano 1 is a reliable marker for ICC in human GI tract.

Materials and methods: Specimens from the wall of stomach, small intestine, and colon were taken from human cadavers and processed for histological and immunohistochemical study using c-Kit and Ano1 primary antibodies.

Results: Interstitial cells of Cajal appeared as bipolar cells, not forming network, in both the circular and longitudinal muscle layers, while in the myenteric area they appeared as multipolar interconnected cells. They were unevenly distributed in and between the muscle layers of the muscularis externa of human GI tract. They were more numerous in the stomach followed by the colon then the small intestine, and more numerous in the myenteric area followed by the circular muscle layer then the longitudinal muscle layer, in the three organs. Our results also showed that Ano1 is a more reliable marker for human ICC than c-Kit.

Conclusions: Interstitial cells of Cajal differed in morphology and were unevenly distributed between muscle layers of muscularis externa and between different parts of human Gl tract. (Folia Morphol 2023; 82, 1: 147-157)

Key words: interstitial cells of Cajal, c-Kit, anoctamin 1, stomach, small intestine, colon

\section{INTRODUCTION}

Gastrointestinal (GI) tract motility is essential for life and is a highly regulated and coordinated process. Research in motility of $\mathrm{Gl}$ tract began with the discovery of spontaneous gastric [3] and colonic [7] contractions. Even after blocking neural activity, Bayliss and Starling [2] discovered that smooth muscle contractions initiating effectual peristalsis still hap-

Address for correspondence: Dr. M. Atteya, Department of Anatomy, College of Medicine, King Saud University, PO Box 2925 (28), Riyadh 11461, Saudi Arabia, tel: +966(11)4699330, mobile: +966502765609, fax: +966(11)4671300, e-mail: mhasan1@ksu.edu.sa

This article is available in open access under Creative Common Attribution-Non-Commercial-No Derivatives 4.0 International (CC BY-NC-ND 4.0) license, allowing to download articles and share them with others as long as they credit the authors and the publisher, but without permission to change them in any way or use them commercially. 
pened, indicating the presence of an internal pacemaker in the gut.

Cajal [5] suggested that interstitial cells of Cajal (ICC) play a key role in motility of GI tract by modulating enteric transmission, and later on Keith [28] proposed ICC as pacemakers. According to Yin and Chen [66], ICC provide various important functions in the Gl tract involving initiation of slow wave electrical activity, synchronisation of pacemaker activity and effective spread of slow waves, transduction of motor nerve impulses from the Gl nervous system, and working as mechanoreceptors to GI muscle stretch [41].

In 1982, Thuneberg [56] surprised GI tract researchers by postulating that ICC in the GI muscles are analogous to the pacemaker cells in the heart, having the potential to function as pacemaker cells and as an impulse conduction system.

Since then, with the accumulation of evidence from morphologic and physiologic studies, this postulate is compatible with experimental observations, and that ICC have the function of either a pacemaker or neuromediator cell in the muscularis of the $\mathrm{Gl}$ tract $[23,30,49,57,65]$. It was revealed to be a distinct mesenchymal cell type $[34,67]$. The demonstration of synapse-related proteins in synaptic specializations between ICC and nerves by immunohistochemistry [4] further established the role of ICC as neuromediator cells.

Cajal [6] was the first to recognise ICC as nerve-like cells near ends of more peripheral nerve fibres and classified them as primitive neurons based on their stainability with silver chromate and methylene blue.

Using light and electron microscopy, Taxi $[54,55]$ named these cells neuronoids to distinguish them from neurons and other cells that were also stained with nerves, such as Schwann cells, fibroblasts, macrophages, and smooth muscle cells. Later on, electron microscopic studies proposed similarity of ICC to either muscle cells $[12,26]$ or fibroblasts $[29,46]$. Langton et al. [33] were the first to report electrical rhythmicity of these cells.

Morphological criteria continued to be the basis of ICC characterisation till Maeda et al. [37] discovered the expression of the tyrosine kinase receptor, c-Kit (CD117), by ICC. This discovery was the landmark in ICC research that has driven it to great progress. To a considerable extent, some ICC do not express c-Kit, such as ICC in the deep muscular plexus in the small intestine of human [59]. Moreover, in addition to ICC, many other cell types express c-Kit, such as neurons, neuroglia, melanocytes, and mast cells [68].

Recently, a calcium activated chloride channel, anoctamin 1 (Ano1), was identified as a selective marker for all subtypes of ICC in the human and mouse GI tract that allows the immunohistochemical identification of these cells instead of c-Kit [15].

Based on ICC anatomical locations, many morphologic types of ICC were defined [18]. Most of GI ICC occur around the myenteric plexus and are called ICC of the myenteric plexus (ICC-MY or ICC-MP). ICC of the circular muscle (ICC-CM) are those found in the circular muscle. ICC of the longitudinal muscle (ICC-LM) are those in the longitudinal muscle. ICC-CM and ICC-LM are collectively known as intramuscular ICC (ICC-IM). ICC of the deep muscular plexus (ICC-DMP) are those located in the deep muscular plexus [32].

The body and antrum of the stomach are more densely populated by ICC than the funds, as the antrum has both ICC-MY and ICC-IM, while the fundus has only ICC-IM [21, 38]. In the antrum, ICC-MY are more densely distributed in the greater curvature than in the lesser curvature $[21,38]$. Many c-Kit-positive ICC-IM were detected in the circular and longitudinal muscle layers and around the myenteric plexus in the pylorus [61].

According to ICC location in different regions and layers of Gl tract, they show specific arrangement, distribution, and cell shape. In the stomach there are regional variations in ICC distribution from cardia to pylorus, while their distribution throughout both the small intestine and colon shows a consistent pattern [32].

Interstitial cells of Cajal show a specific distribution, arrangement and cell shape depending on their location within various regions and tissue layers of the GI tract. Hence, they are classified into several subtypes. The stomach shows distinct regional variations in the distribution of subtypes of ICC from the cardia to pylorus, whereas the small intestine and colon both seem to retain nearly the same distribution pattern of subtypes of ICC throughout each organ.

Most studies on ICC used the animal model and only few studies were done on human samples, and even those were limited to one or two organs of the $\mathrm{Gl}$ tract, due to difficulty of obtaining samples from different organs of gut of the same person during performing surgeries. Because of the difficulty of collecting amounts of human Gl tract tissue enough for research have restricted the understanding of the 

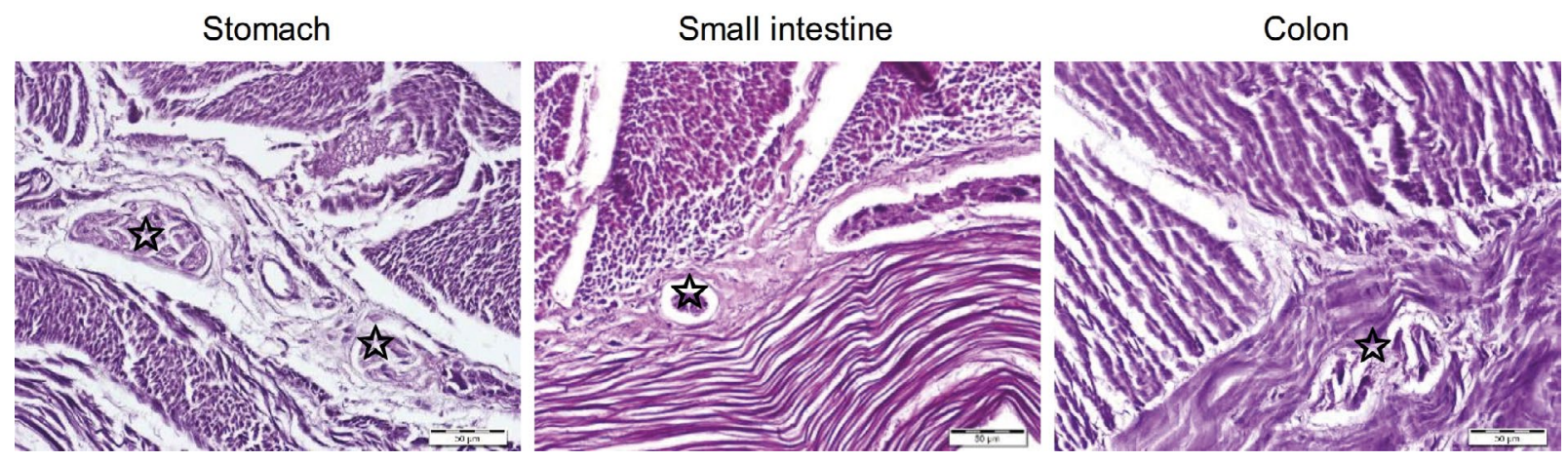

Figure 1. Haematoxylin and eosin-stained sections in muscularis externa of stomach, small intestine, and colon, showing inner circular, outer longitudinal, and myenteric plexuses (asterisks) between the circular and longitudinal layers. There is no apparent interstitial cells of Cajal (scale bars $50 \mu \mathrm{m}$ ).

nature of GI tract motility and human ICC in normal or diseased Gl tract functions. Therefore, our study was conducted on samples from the three main different Gl tract regions (stomach, small intestine, and large intestine) that were obtained from human cadavers.

The study focused on the morphology and distribution of ICC in the muscularis externa that includes the inner circular, outer longitudinal muscle layers and myenteric plexus between them, using immunohistochemistry staining methods. The study also aimed to determine the distribution of immune reactivity of Ano1 compared with c-Kit, and to determine if Ano1 is a reliable marker for ICC in human GI tract.

\section{MATERIALS AND METHODS}

\section{Human samples}

Samples were obtained from 10 male human cadavers (aged 40-60 years), which were available in the Department of Anatomy, College of Medicine, King Saud University. From each cadaver small specimens about, $1 \mathrm{~cm} \times 0.5 \mathrm{~cm}$, were excised from the greater curvature of the stomach corpus, first part of duodenum, and proximal colon.

\section{Histological and immunohistochemical study}

Full thickness specimens of the wall of stomach, duodenum, and colon were fixed in enough amounts (5-10 times of tissue volume) of 4\% paraformaldehyde for 24 hours at room temperature. Fixed tissues were processed for preparation of paraffin blocks. The blocks were cut at $5 \mu \mathrm{m}$ thickness and sections were mounted onto glass slides to be ready for staining.

Haematoxylin and eosin (H\&E) staining. On ordinary glass slides some sections were de-paraffinised to be stained with H\&E solutions then mounted with DPX mounting medium.
Immunostaining using anti-c-Kit (CD117) and anti-Ano1 antibodies. Sections from the stomach, small intestine, and colon were immunostained with anti-c-Kit (ab5505) rabbit polyclonal primary antibody (dilution of 1:1000) and anti-Ano1 (ab53212) rabbit polyclonal primary antibody (dilution of 1:1000), according to the manufacturer's data sheets.

Quantification of immune-positive cells. The numbers of c-Kit- and Ano1-positive cells in the circular, myenteric, and longitudinal layers of muscularis externa of stomach, small intestine, and colon were counted at $\times 200$ magnification. Cells in 30 fields from three nonadjacent sections were counted (10 fields per section) [15].

\section{Statistical analysis}

All data were expressed as mean \pm standard error of the mean (SEM). Statistical analysis was performed using IBM SPSS Statistics 22 statistical software. One-way analysis of variance (ANOVA) was used for an overall comparison between the study organs and layers of muscularis externa, followed by Bonferroni test for pairwise comparisons. Differences were considered significant when $p$ was equal to or less than 0.05 .

\section{RESULTS}

\section{Haematoxylin and eosin (Fig. 1)}

Histological examination of $\mathrm{H} \& \mathrm{E}$-stained sections of human stomach, small intestine, and colon showed normal layers of the muscularis externa; circular layer, myenteric layer (neuronal plexuses area), between circular and longitudinal layers, and outer longitudinal layer. ICC were not clearly identified by H\&E staining in the three organs (Fig. 1). 


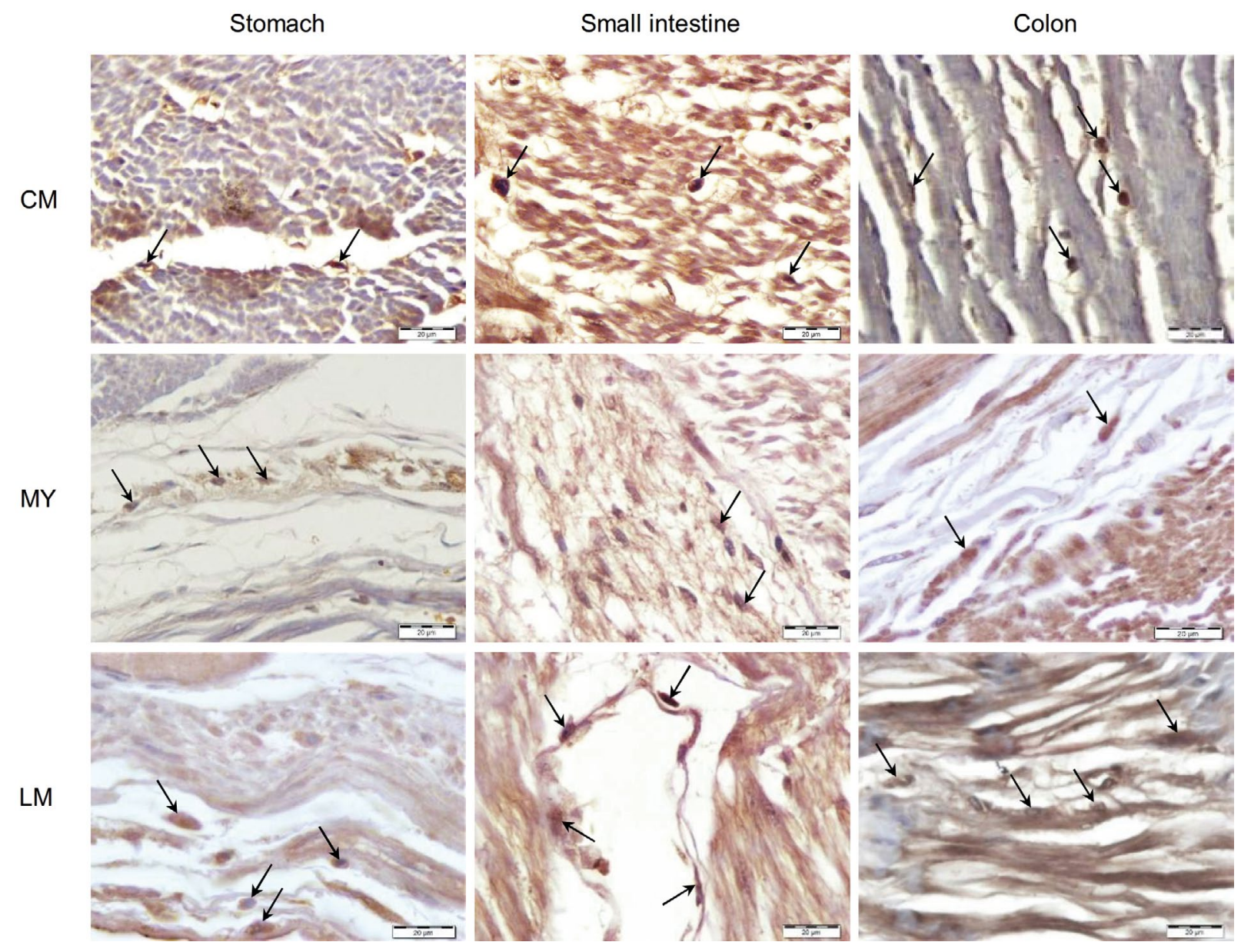

Figure 2. c-Kit immunostaining of muscularis externa of stomach, small intestine, and colon. Most of c-Kit-positive cells (arrows) of the circular (CM) and longitudinal (LM) muscle layers were spindle shaped, while those of the myenteric (MY) area were oval and multipolar cells (scale bars $20 \mu \mathrm{m}$ ).

\section{Anti-c-Kit immunohistochemistry (Fig. 2, Table 1)}

c-Kit immunostaining gave a dark brown coloration of cytoplasm of many types of cells, such as ICC, fibroblasts, and mast cells. Identification of ICC by c-Kit was mainly by their thin processes, but it was difficult to count ICC accurately. Counting c-Kit-positive cells (Table 1) gave higher numbers than counting Ano1-positive cells (Tables 2, 3). ICC of muscularis externa were classified according to their distribution into ICC of the inner circular muscle layer (ICC-CM), ICC of the myenteric plexuses layer (ICC-MY), and ICC of the outer longitudinal muscles layer (ICC-LM).

c-Kit immunostaining of circular layer (ICC-CM). In the stomach, C-Kit-positive ICC appeared spindle shaped with few long processes. They were parallel to the longitudinal axis of the smooth muscle cells surrounding them. They did not form a network. In the small intestine, c-Kit-positive ICC were spindle shaped similar to those of the stomach, but they had special contacts with both neurons and smooth muscle cells. In the colon, most c-Kit-positive ICC were small, spindle shaped cells with few processes. They ran parallel to the smooth muscle cells.

c-Kit immunostaining of myenteric plexus region (ICC-MY). In the stomach, c-Kit-positive ICC appeared multipolar or stellate shaped. They were connected together by branching processes forming a network around myenteric plexuses. In the small intestine, c-Kit-positive ICC were also multipolar or stellate shaped and formed bundles of up to five cells with overlapping processes. They extended to the circular and longitudinal layers. In the colon, c-Kit-positive ICC were many. They were multipolar with their processes connecting with each other and forming a network around myenteric plexuses.

c-Kit immunostaining of longitudinal muscle layer (ICC-LM). In the stomach, c-Kit-positive ICC were spindle shaped cells scattered in-between the smooth longitudinal muscle cells. In the small intestine, c-Kit-positive ICC appeared as bipolar flat spindle 
Table 1. Average counts (mean \pm standard error) of c-Kit-positive cells in the layers of muscularis externa: comparing respective layers between stomach, small intestine, and colon

\begin{tabular}{lccc}
\hline & Stomach & Small intestine & Colon \\
\hline CM & $47.4 \pm 2.04$ & $36.2 \pm 1.7$ & $39.2 \pm 0.86$ \\
P1 & & $0.001^{*}$ & $0.011^{*}$ \\
P2 & $0.001^{*}$ & & 0.642 \\
MY & $119.2 \pm 5.23$ & $55.0 \pm 1.64$ & $70.4 \pm 1.75$ \\
P1 & & $0.000^{*}$ & $0.000^{*}$ \\
P2 & $0.000^{*}$ & & $0.02^{*}$ \\
LM & $45.0 \pm 1.82$ & $34.2 \pm 1.39$ & $38.2 \pm 1.28$ \\
P1 & & $0.001^{*}$ & $0.024^{*}$ \\
P2 & $0.001^{*}$ & & 0.259 \\
\hline
\end{tabular}

${ }^{*}$ Significant difference $(\mathrm{p} \leq 0.05)$; $\mathrm{P} 1$ - versus stomach, $\mathrm{P} 2$ - versus small intestine; $\mathrm{CM}$ - circular muscle layer; MY — myenteric layer; LM — longitudinal muscle layer

Table 2. Average counts (mean \pm standard error) of anoctamin 1-positive interstitial cells of Cajal in the layers of muscularis externa: comparing respective layers between stomach, small intestine, and colon

\begin{tabular}{lccc}
\hline & Stomach & Small intestine & Colon \\
\hline CM & $41.6 \pm 1.78$ & $31.2 \pm 1.24$ & $37.4 \pm 1.47$ \\
P1 & & $0.001^{*}$ & 0.219 \\
P2 & $0.001^{*}$ & & 0.06 \\
MY & $104.8 \pm 1.85$ & $45.2 \pm 1.16$ & $59.8 \pm 1.66$ \\
P1 & & $0.000^{*}$ & $0.000^{*}$ \\
P2 & $0.000^{*}$ & & $0.000^{*}$ \\
LM & $39.8 \pm 2.46$ & $29.4 \pm 0.87$ & $33.4 \pm 1.63$ \\
P1 & & $0.004^{*}$ & 0.077 \\
P2 & $0.004^{*}$ & & 0.412 \\
\hline
\end{tabular}

${ }^{*}$ Significant difference $(\mathrm{p} \leq 0.05) ; \mathrm{P} 1$ — versus stomach; P2 — versus small intestine; $\mathrm{CM}$ — circular muscle layer; MY — myenteric layer; LM — longitudinal muscle layer

Table 3. Average counts (mean \pm standard error) of anoctamin 1-positive interstitial cells of Cajal in the layers of muscularis externa: comparing layers within each of stomach, small intestine, and colon

\begin{tabular}{lccc}
\hline & CM & MY & LM \\
\hline Stomach & $41.6 \pm 1.78$ & $104.8 \pm 1.85$ & $40.2 \pm 2.33$ \\
P1 & & $0.000^{*}$ & 1.00 \\
P2 & $0.000^{*}$ & & $0.000^{*}$ \\
Small intestine & $31.2 \pm 1.24$ & $45.2 \pm 1.16$ & $29.4 \pm 0.87$ \\
P1 & & $0.000^{*}$ & 0.811 \\
P2 & $0.000^{*}$ & & $0.000^{*}$ \\
Colon & $37.4 \pm 1.47$ & $59.8 \pm 1.66$ & $33.4 \pm 1.63$ \\
P1 & & $0.000^{*}$ & 0.300 \\
P2 & $0.000^{*}$ & & $0.000^{*}$ \\
\hline
\end{tabular}

${ }^{*}$ Significant difference $(\mathrm{p} \leq 0.05)$; P1 — versus $\mathrm{CM}$; P2 — versus MY; CM — circular muscle layer; MY — myenteric layer; LM — longitudinal muscle layer cells with a large body and few processes within the fibres of longitudinal smooth muscle layer. In the colon, c-Kit-positive ICC were spindle shaped with few processes.

\section{Anti-Ano1 immunohistochemistry (Fig. 3, Table 2)}

Ano1-positive cells were mainly ICC because Ano1 specifically stains their cytoplasm dark brown.

Ano1 immunostaining of ICC in the circular muscle layer (ICC-CM). In the stomach, there were many Ano1-positive ICC between smooth muscle fibres of the circular muscle layer. Most of them were arranged in interconnected groups while others are separately scattered. They had very fine few processes that extended to the surrounding smooth muscle fibres. They were spindle shaped with small rounded or oval nuclei. ICC-CM were significantly more numerous than those of the small intestine and insignificantly more numerous than those of the colon. In the small intestine, Ano1-positive ICC in the circular layer were larger in size and stellate in shape. They had few short processes connected with surrounding muscle fibres. They were significantly fewer than those of the stomach and insignificantly fewer than those of the colon. In the colon, most Ano1-positive ICC were small and spindle shaped. They had few thin processes connecting them with neighbouring muscle fibres and ICCs. They were more numerous than those of the small intestine but less numerous than those of the stomach, with insignificant differences (Fig. 3, Table 2).

Ano1 immunostaining of ICC in the myenteric plexus region (ICC-MY). In the stomach, there were many Ano1-positive ICC in the myenteric plexuses and the connective tissue surrounding them. They were stellate shaped cells with oval nuclei. Some of them formed chain-like structures around plexuses while others were present inside and outside the plexuses. Their number was significantly more numerous than those of the small intestine and colon. In the small intestine, most of Ano1-positive ICC were inside the plexuses. They were small and stellate shape and connected by their processes. They were significantly less numerous than those of the stomach and colon. In the colon, Ano1-positive ICC were mostly small and stellate shaped with oval or rounded nuclei. They had thin processes connecting them, forming chain-like structures around neurons of the plexuses. They were significantly more numerous than those of the small intestine and significantly less numerous than those of the stomach (Fig. 3, Table 2). 
Stomach

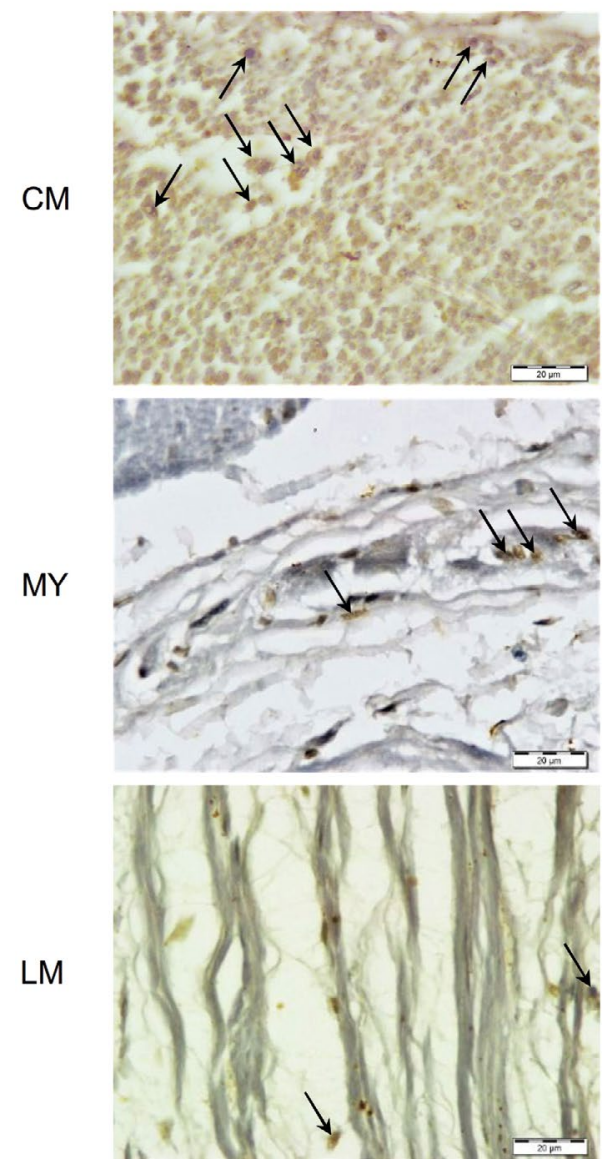

Small intestine
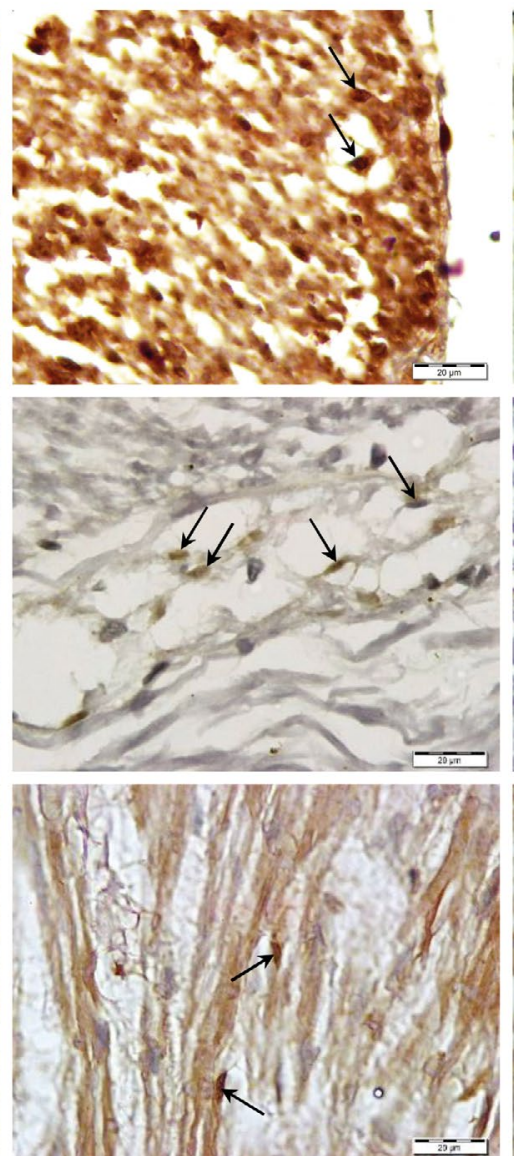

Colon
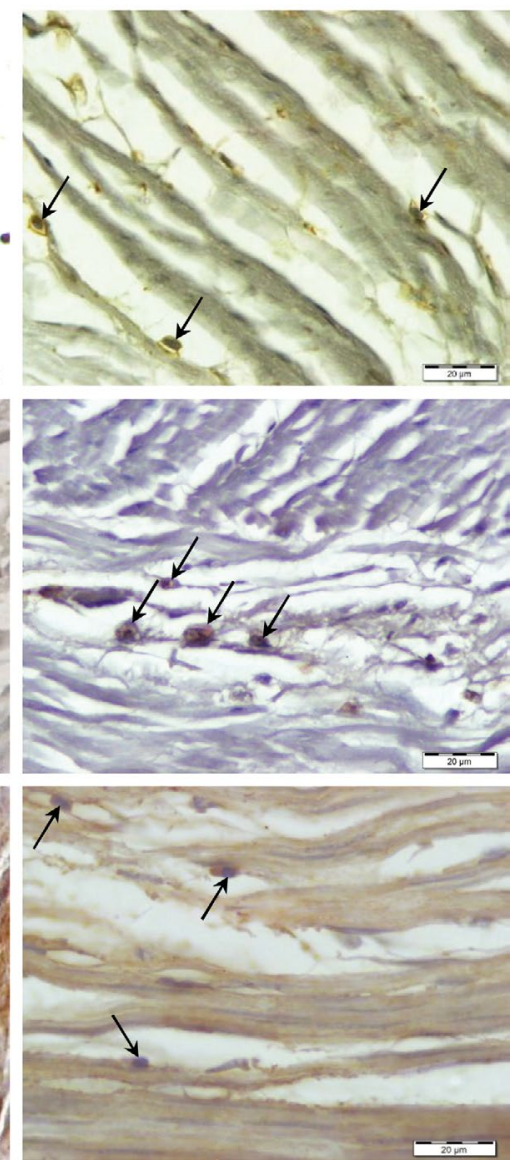

Figure 3. Anoctamin 1 immunostaining of muscularis externa of stomach, small intestine, and colon. Anoctamin 1-positive interstitial cells of Cajal (arrows) of the circular (CM) and longitudinal (LM) muscle layers were spindle shaped, while those of the myenteric (MY) area were stellate multipolar cells (scale bars $20 \mu \mathrm{m}$ ).

Ano1 immunostaining of ICCs in the longitudinal muscle layer (ICC-LM). In the stomach, Ano1-positive ICC between longitudinal smooth muscle fibres were spindle shaped cells with small oval nuclei. They had many long processes that formed a network with the muscle fibres. They were significantly more numerous than those of the small intestine but insignificantly more numerous than those of the colon. In the small intestine, Ano1-positive ICC were scattered between smooth muscle cells of longitudinal muscle layer. They were small and spindle shaped with small flat nuclei. They were significantly fewer than those of the stomach and insignificantly fewer than those of the colon. In the colon, Ano1-positive ICC were spindle shaped cells with oval nuclei. They were scattered between smooth muscle fibres and connected to them by their processes. They were more numerous than those of the small intestine but less numerous than those of the stomach, with insignificant differences (Fig. 3, Table 2).
Ano1-positive ICC distribution in the three layers of muscularis externa of each organ. In each of the three organs, ICC were significantly more numerous in the myenteric area than in either the circular or the longitudinal muscle layers $(p<0.05)$, while the differences in ICC numbers between the circular and the longitudinal muscle layers were statistically insignificant $(p>0.05)$ (Table 3$)$.

\section{DISCUSSION}

In the present study, we investigated the distribution and the number of c-Kit and Ano1 immunoreactive cells in the muscularis externa of human stomach, small intestine, and colon. The specimens were examined by using anti-c-kit immunohistochemistry, known to reliably identify the location of ICC and provide information on their distribution and density [43]. However, besides being a marker for ICC, c-Kit have been shown to be expressed also in variety of normal tissues such as brain, placenta and lung [48] 
as well as malignant tumours and gastric carcinoma cell line $[19,20]$. Additionally, c-Kit has also been shown to be activated by mutations such as in some human cancers such as human gastric carcinomas [14, 19], gastrointestinal stromal tumour (GIST) [31], small cell lung cancer [20], and colorectal cancer [44]. Therefore, ICC seem to have many capabilities, and they might be related to growth of tumours.

Another marker, Ano1, considered more reliable than the c-Kit for ICC identification [36], was recently found. It is a $\mathrm{Ca}^{2+}$-activated chloride channel necessary for generation of slow wave and lacking any effect on differentiation of ICC [24]. Ano1 is thought to be expressed specifically on ICC. Different from c-Kit, Ano1 plays an important role in pacemaker activity of ICC. For evaluating the ICC network, Ano1 is better than c-Kit because it is more specific and functionally more important. The abnormal distribution of Ano1-positive ICC in the aganglionic colon of Hirschsprung's disease contributes to the persistent bowel symptoms after some pull-through surgeries $[3,10]$.

In the current study we used samples from human cadavers, because access to enough fresh $\mathrm{Gl}$ tissue from normal human for research has been a major challenge. Such tissue is frequently restricted to small amounts gained from biopsies. In some situations, larger amounts of human Gl tissue can be obtained from sleeve gastrectomy or GI cancer surgeries. Some histological studies have identified c-Kit- and Ano1-positive ICC in gastric tissue obtained from sleeve gastrectomy $[15,16,53]$ and gastric cancer surgeries $[40,45]$. Similar studies have also been done on small intestinal tissue from gastric bypass surgeries $[8,15,24,35,52]$ and colon tissue from colon cancer surgeries $[9,15,16,27]$. Although ICC in these GI tissues appeared morphologically normal, still the sources of these tissues were from unhealthy donors (e.g., obesity or cancer patients).

By the end of the last century, ICC were suggested to be regulators of $\mathrm{Gl}$ motility in animals $[13,17,59]$, and the distribution was found to be uneven in the stomach, small intestine and colon, with regional differences. For example, in murine stomach, ICC-MY density was greater at the antrum and corpus than at the fundus while ICC-IM were denser at the fundus and corpus than at the antrum [51]. In addition, ICC-IM density was lower at the lesser curvature than the greater curvature [21, 51]. Therefore, in our study, we preferred to use samples from the greater curvature of the stomach corpus. According to Vanderwinden et al. [60] who found more concentration of ICC in the muscularis externa of the first part of duodenum, our samples of small intestine were taken from the duodenum. As for the large intestine, our samples were taken from the proximal colon in accordance with Hwang et al. [24] who found much higher density of colonic ICC at the proximal part, where strong haustral contractions begin.

The morphological features of GI tract ICC previously described in the literature were mostly based on observations in laboratory animals using immunohistochemical staining for c-Kit and electron microscopy. In the current research we aimed to study ICC in human muscularis externa using two types of primary antibodies; c-Kit (the most common ICC kit, but non-specific) and Ano1 (less commonly used but more specific) as the specimens from cadavers were unsuitable for electron microscopic analysis.

Almost all ICC subtypes have similar ultrastructural features, such as numerous mitochondria, intermediate filaments, and gap junctions with each other and with smooth muscle cells. Additionally, according to animal species and anatomical location, some ICC subtypes have features like smooth muscle cells such as an external lamina, dense bodies, caveolae, and subsurface cisterns.

Depending on ICC localisation in the muscularis externa, they have been grouped into submuscular, intramuscular, myenteric, and subserosal. According to their morphology, they were described as either stellate or bipolar. They were also classified based on their function into pacemakers, neuromediators, and mechanoreceptors. Moreover, some authors reported some accordance between morphology, localisation, and function of the various ICC subtypes $[50,66]$.

In this study, ICC-CM were mainly bipolar cells oriented parallel to the longitudinal axis of the surrounding smooth muscle cells. These cells did not form their own network. However, the distribution and density of ICC-CM differed from one organ to the other. For example, in the small intestine they frequently showed secondary cytoplasmic processes and were scantily distributed in relation to relatively thicker nerve bundles. They did not form their own cellular network. In comparison, ICC-CM of the stomach and colon were elongated and spindle-shaped but were heavily distributed in relation to nerve bundles. Similar finding were reported by Komuro [32]. 
ICC-MY were multipolar cells that had three to five primary cytoplasmic branches that further gave secondary and tertiary processes that interconnected with their equivalents. These branches formed a network surrounding the myenteric plexus. Similar description was depicted by Komuro [32]. These ICC-MY were found to be closely related to myenteric nerves and have receptors for many neurotransmitters [62] and hormones (e.g., cholecystokinin) [42]. In the small intestine, we noticed that ICC-MY were arranged in bundles of up to five cells, with intersecting processes. These bundles extended between the surrounding muscle cells of the longitudinal and circular layers and into the interlamellar septa, which was in accordance with the description reported by Rumessen et al. [47]. Many researchers referred the function of ICC-MY network to its role as the primary pacemaker region in the stomach and small intestine and to be involved in generating higher frequency activity in the colon $[1,11,22,58,64]$.

In our study, the morphological features of ICC-LM were similar to that of ICC-CM, but they were usually less numerous than the latter, nearly in the three regions of $\mathrm{Gl}$ tract examined. Similar findings were reported by Komuro [31].

Our results showed higher numbers of c-Kit-positive cells than Ano1-positive cells. This difference can be attributed to cross staining of some other cells as fibroblasts and mast cells by c-Kit while Ano1 stained ICC only. As ICC Ano1-immunoreactivity was more specific than that of c-Kit [15], we relied on the count of Ano1-positive ICC in each layer of muscularis externa of stomach, small intestine, and colon at $\times 200$ magnification.

Interstitial cells of Cajal were distributed in the three areas of muscularis externa. They were more concentrated in the myenteric area of the three organs. Our results also showed more predominance of ICC in the three layers of the stomach than in the small intestine and colon, while the small intestine showed less numbers of ICC than the stomach and colon.

In general, the number of ICC in muscularis externa of the stomach and colon was more than that of the small intestine, but this difference was not statistically significant for both ICC-CM and ICC-LM, while in myenteric area, ICC-MY of the stomach were significantly more than those of the small intestine and colon, and ICC-MY of the colon were significantly more than those of the small intestine. These findings can be explained by the slow peristaltic movement of the small intestine (to allow perfect absorption of digested food) if compared with that of the stomach (to digest food and control evacuation of chime) and colon (to control evacuation of waste products).

Regarding the distribution of ICC in the three areas of muscularis externa, we noticed that they were significantly more concentrated in the myenteric area (between circular and longitudinal muscle layers), followed by the circular and then the longitudinal muscle layers. This coincides with the explanation given by Hanani et al. [18], Komuro [32] who found that most ICC in the GI tract occur in the area of the myenteric plexus followed by the circular muscle layer, while ICC were less in the longitudinal muscle layer.

In our study, the density of ICC was significantly higher at the myenteric area than at the circular and longitudinal muscle layers of the muscularis externa. This distinctive regional variation in ICC distribution seemed to be associated with distinctive physiological function of each GI tract layer as reported by Ibba Manneschi et al. [25], Nemeth and Puri [39], Wang et al. [63], who investigated the physiological function of ICC in human stomach, small intestine and colon.

\section{CONCLUSIONS}

In conclusion, ICC appeared as bipolar cells, not forming network, in both the circular and longitudinal muscle layers, while in the myenteric area they appeared as multipolar interconnected cells. They were unevenly distributed in and between the muscle layers of the muscularis externa of human GI tract. They were more numerous in the stomach followed by the colon then the small intestine, and more numerous in the myenteric area followed by the circular muscle layer then the longitudinal muscle layer, in the three organs. Our results also showed that Ano1 is a more reliable marker for human ICC than c-Kit.

\section{Acknowledgements}

The authors sincerely thank those who donated their bodies to science so that research could be performed. Results from such research can potentially increase mankind's overall knowledge that can then improve patient care. Therefore, these donors and their families deserve our highest gratitude.

Conflict of interest: None declared 


\section{REFERENCES}

1. Bayguinov PO, Hennig GW, Smith TK. Ca2+ imaging of activity in ICC-MY during local mucosal reflexes and the colonic migrating motor complex in the murine large intestine. J Physiol. 2010; 588(Pt 22): 4453-4474, doi: 10.1113/ jphysiol.2010.196824, indexed in Pubmed: 20876203.

2. Bayliss WM, Starling EH. The movements and innervation of the small intestine. J Physiol. 1899; 24(2): 99-143, doi: 10.1113/jphysiol.1899.sp000752, indexed in Pubmed: 16992487.

3. Beaumont W. Nutrition Classics. Experiments and observations on the gastric juice and the physiology of digestion. By William Beaumont. Plattsburgh. Printed by F. P. Allen. 1833. Nutr Rev. 1977; 35(6): 144-145, doi: 10.1111/j.1753-4887.1977.tb06570.x, indexed in Pubmed: 327355.

4. Beckett EAH, Takeda $Y$, Yanase $H$, et al. Synaptic specializations exist between enteric motor nerves and interstitial cells of Cajal in the murine stomach. J Comp Neurol. 2005; 493(2): 193-206, doi: 10.1002/cne.20746, indexed in Pubmed: 16255030.

5. Cajal SR. Textura del sistema nervioso del hombre y de los vertebrados. Vol. 2. Imprenta y librería de Nicolás Moya, Madrid 1899.

6. Cajal SR. Histologie du système nerveux de l'homme \& des vertébrés. Vol. 2. Cervelet, cerveau moyen, rétine, couche optique, corps strié, écorce cérébrale générale \& régionale, grand sympathique. A. Maloine, Paris 1911: 891-942.

7. Cannon WB. The movements of the intestines studied by means of the röntgen rays. Am J Physiol-Legacy Content. 1902; 6(5): 251-277, doi: 10.1152/ajplegacy.1902.6.5.251.

8. Chen $H$, Redelman $D$, Ro $S$, et al. Selective labeling and isolation of functional classes of interstitial cells of Cajal of human and murine small intestine. Am J Physiol Cell Physiol. 2007; 292(1): C497-C507, doi: 10.1152/ajpcell.00147.2006, indexed in Pubmed: 16943245.

9. Chen ZH, Zhang YC, Jiang WF, et al. Characterization of interstitial Cajal progenitors cells and their changes in Hirschsprung's disease. PLoS One. 2014; 9(1): e86100, doi: 10.1371/journal.pone.0086100, indexed in Pubmed: 24475076.

10. Coyle D, Kelly DAM, O'Donnell AM, et al. Use of anoctamin 1 (ANO1) to evaluate interstitial cells of Cajal in Hirschsprung's disease. Pediatr Surg Int. 2016; 32(2): 125-133, doi: 10.1007/s00383-015-3822-9, indexed in Pubmed: 26510736.

11. Dickens EJ, Hirst GD, Tomita T. Identification of rhythmically active cells in guinea-pig stomach. J Physiol. 1999; 514 ( Pt 2)(Pt 2): 515-531, doi: 10.1111/j.14697793.1999.515ae.x, indexed in Pubmed: 9852332.

12. Faussone Pe, Cortesini $C$, Romagnoli P. [Ultrastructure of the tunica muscularis of the cardial portion of the human esophagus and stomach, with special reference to the so-called Cajal's interstitial cells]. Arch Ital Anat Embriol. 1977; 82(2): 157-177, indexed in Pubmed: 613989.

13. Faussone-Pellegrini MS, Cortesini C. Ultrastructural features and localization of the interstitial cells of Cajal in the smooth muscle coat of human esophagus. J Submicrosc Cytol. 1985; 17(2): 187-197, indexed in Pubmed: 3999182.
14. Fujiwara T, Motoyama T, Ishihara N, et al. Characterization of four new cell lines derived from small-cell gastrointestinal carcinoma. Int J Cancer. 1993; 54(6): 965-971, doi: 10.1002/ijc.2910540617, indexed in Pubmed: 8392984.

15. Gomez-Pinilla PJ, Gibbons SJ, Bardsley MR, et al. Ano1 is a selective marker of interstitial cells of Cajal in the human and mouse gastrointestinal tract. Am J Physiol Gastrointest Liver Physiol. 2009; 296(6): G1370-G1381, doi: 10.1152/ ajpgi.00074.2009, indexed in Pubmed: 19372102.

16. Gomez-Pinilla PJ, Gibbons SJ, Sarr MG, et al. Changes in interstitial cells of cajal with age in the human stomach and colon. Neurogastroenterol Motil. 2011; 23(1): 36-44, doi: 10.1111/j.1365-2982.2010.01590.x, indexed in Pubmed: 20723073.

17. Hagger R, Gharaie S, Finlayson C, et al. Regional and transmural density of interstitial cells of Cajal in human colon and rectum. Am J Physiol. 1998; 275(6): G1309G1316, doi: 10.1152/ajpgi.1998.275.6.G1309, indexed in Pubmed: 9843767.

18. Hanani M, Farrugia G, Komuro T. Intercellular coupling of interstitial cells of cajal in the digestive tract. Int Rev Cytol. 2004; 242: 249-282, doi: 10.1016/s00747696(04)42006-3.

19. Hassan S, Kinoshita Y, Kawanami C, et al. Expression of protooncogene c-kit and its ligand stem cell factor (SCF) in gastric carcinoma cell lines. Dig Dis Sci. 1998; 43(1): 8-14, doi: 10.1023/a:1018851415704, indexed in Pubmed: 9508539.

20. Hibi K, Takahashi T, Sekido $Y$, et al. Coexpression of the stem cell factor and the c-kit genes in small-cell lung cancer. Oncogene. 1991; 6(12): 2291-2296, indexed in Pubmed: 1722571.

21. Hirst GDS, Beckett EAH, Sanders KM, et al. Regional variation in contribution of myenteric and intramuscular interstitial cells of Cajal to generation of slow waves in mouse gastric antrum. J Physiol. 2002; 540(Pt 3): 1003-1012, doi: 10.1113/ jphysiol.2001.013672, indexed in Pubmed: 11986385.

22. Huizinga JD, Thuneberg $L$, Klüppel $M$, et al. W/kit gene required for interstitial cells of Cajal and for intestinal pacemaker activity. Nature. 1995; 373(6512): 347-349, doi: 10.1038/373347a0, indexed in Pubmed: 7530333.

23. Huizinga JD, Thuneberg L, Vanderwinden JM, et al. Interstitial cells of Cajal as targets for pharmacological intervention in gastrointestinal motor disorders. Trends Pharmacol Sci. 1997; 18(10): 393-403, doi: 10.1016/ s0165-6147(97)01108-5.

24. Hwang SJ, Blair PJA, Britton FC, et al. Expression of anoctamin 1/TMEM16A by interstitial cells of Cajal is fundamental for slow wave activity in gastrointestinal muscles. J Physiol. 2009; 587(Pt 20): 4887-4904, doi: 10.1113/ jphysiol.2009.176198, indexed in Pubmed: 19687122.

25. Ibba Manneschi L, Pacini S, Corsani L, et al. Interstitital cells of Cajal in the human stomach: distribution and relationship with enteric innervation. Histol Histopathol. 2004; 19(4): 1153-1164, doi: 10.14670/HH-19.1153, indexed in Pubmed: 15375758.

26. Imaizumi M, Hama K. An electron microscopic study on the interstitial cells of the gizzard in the love-bird (Uroloncha domestica). Z Zellforsch Mikrosk Anat. 1969; 97(3): 351-357, doi: 10.1007/BF00968841, indexed in Pubmed: 4906488. 
27. Kashyap P, Gomez-Pinilla PJ, Pozo MJ, et al. Immunoreactivity for Ano1 detects depletion of Kit-positive interstitial cells of Cajal in patients with slow transit constipation. Neurogastroenterol Motil. 2011; 23(8): 760-765, doi: 10.1111/j.13652982.2011.01729.x, indexed in Pubmed: 21585622.

28. Keith $A$. The cabendish lecture ona new theory of the causation of enterostasis. Lancet. 1915; 186(4799): 371-375, doi: 10.1016/s0140-6736(01)53737-x.

29. Komuro T. Three-dimensional observation of the fibroblast-like cells associated with the rat myenteric plexus, with special reference to the interstitial cells of Cajal. Cell Tissue Res. 1989; 255(2): 343-351, doi: 10.1007/ BF00224117, indexed in Pubmed: 2924337.

30. Komuro T. Comparative morphology of interstitial cells of Cajal: Ultrastructural characterization. Microsc Res Tech. 1999; 47(4): 267-285, doi: 10.1002/(sici)10970029(19991115)47:4<267::aid-jemt5>3.0.co;2-o.

31. Komuro T. Morphological features of interstitial cells of Cajal. In: Kitamura Y, Miettinenn M, Hirota S, Kanakura Y (eds.). Gastrointestinal Stromal Tumor (GIST): from pathology to molecular target therapy, Gann Monograph on Cancer Research No 53. Japan Scientific Societies Press \& Karger, Tokyo, Basel 2004: 109-134.

32. Komuro T. Structure and organization of interstitial cells of Cajal in the gastrointestinal tract. J Physiol. 2006; 576(Pt 3): 653-658, doi: 10.1113/jphysiol.2006.116624, indexed in Pubmed: 16916909.

33. Langton P, Ward SM, Carl A, et al. Spontaneous electrical activity of interstitial cells of Cajal isolated from canine proximal colon. Proc Natl Acad Sci U S A. 1989; 86(18): 7280-7284, doi: 10.1073/pnas.86.18.7280, indexed in Pubmed: 2550938.

34. Lecoin L, Gabella G, Le Douarin N. Origin of the c-kit-positive interstitial cells in the avian bowel. Development. 1996; 122(3): 725-733, doi: 10.1242/dev.122.3.725, indexed in Pubmed: 8631250.

35. Lee HT, Hennig GW, Fleming NW, et al. The mechanism and spread of pacemaker activity through myenteric interstitial cells of Cajal in human small intestine. Gastroenterology. 2007; 132(5): 1852-1865, doi: 10.1053/j. gastro.2007.02.049, indexed in Pubmed: 17484879.

36. Loera-Valencia R, Wang $X Y$, Wright GWJ, et al. Ano1 is a better marker than c-Kit for transcript analysis of single interstitial cells of Cajal in culture. Cell Mol Biol Lett. 2014; 19(4): 601-610, doi: 10.2478/s11658-014-0214-4, indexed in Pubmed: 25338768.

37. Maeda H, Yamagata A, Nishikawa S, et al. Requirement of c-kit for development of intestinal pacemaker system. Development. 1992; 116(2): 369-375, doi: 10.1242/ dev.116.2.369, indexed in Pubmed: 1283735.

38. Mazet B, Raynier C. Interstitial cells of Cajal in the guinea pig gastric antrum: distribution and regional density. Cell Tissue Res. 2004; 316(1): 23-34, doi: 10.1007/s00441-0030835-9, indexed in Pubmed: 14986098.

39. Nemeth L, Puri P. Three-dimensional morphology of c-Kit-positive cellular network and nitrergic innervation in the human gut. Arch Pathol Lab Med. 2001; 125(7): 899-904, doi: 10.5858/2001-125-0899-TDMOCK, indexed in Pubmed: 11419974.

40. Park KS, Cho KB, Hwang IIS, et al. Characterization of smooth muscle, enteric nerve, interstitial cells of Cajal, and fibroblast-like cells in the gastric musculature of patients with diabetes mellitus. World J Gastroenterol. 2016; 22(46): 10131-10139, doi: 10.3748/wjg.v22.i46.10131, indexed in Pubmed: 28028361.

41. Pasternak A, Szura M, Gil K, et al. Interstitial cells of Cajal - systematic review. Folia Morphol. 2016; 75(3): 281-286, doi: 10.5603/FM.a2016.0002, indexed in Pubmed: 26806433.

42. Patterson LM, Zheng $\mathrm{H}$, Ward SM, et al. Immunohistochemical identification of cholecystokinin A receptors on interstitial cells of Cajal, smooth muscle, and enteric neurons in rat pylorus. Cell Tissue Res. 2001; 305(1): 11-23, doi: 10.1007/s004410100402, indexed in Pubmed: 11512662.

43. Radenkovic G, Savic V, Mitic D, et al. Development of c-kit immunopositive interstitial cells of Cajal in the human stomach. J Cell Mol Med. 2010; 14(5): 1125-1134, doi: 10.1111/j.1582-4934.2009.00725.x, indexed in Pubmed: 19298525.

44. Reed J, Ouban A, Schickor FK, et al. Immunohistochemical staining for c-Kit (CD117) is a rare event in human colorectal carcinoma. Clin Colorectal Cancer. 2002; 2(2): 119-122, doi: 10.3816/CCC.2002.n.018, indexed in Pubmed: 12453327

45. Rhee PL, Lee JiY, Son HJ, et al. Analysis of pacemaker activity in the human stomach. J Physiol. 2011; 589(Pt 24): 6105-6118, doi: 10.1113/jphysiol.2011.217497, indexed in Pubmed: 22005683.

46. Richardson KC. Electronmicroscopic observations on Auerbach's plexus in the rabbit, with special reference to the problem of smooth muscle innervation. Am J Anat. 1958; 103(1): 99-135, doi: 10.1002/aja.1001030105, indexed in Pubmed: 13626839.

47. Rumessen J, Mikkelsen H, Qvortrup K, et al. Ultrastructure of interstitial cells of Cajal in circular muscle of human small intestine. Gastroenterology. 1993; 104(2): 343-350, doi: 10.1016/0016-5085(93)90400-7, indexed in Pubmed: 8425676.

48. Rygaard K, Nakamura T, Spang-Thomsen M. Expression of the proto-oncogenes c-met and c-kit and their ligands, hepatocyte growth factor/scatter factor and stem cell factor, in SCLC cell lines and xenografts. Br J Cancer. 1993; 67(1): 37-46, doi: 10.1038/bjc.1993.7, indexed in Pubmed: 7678980.

49. Sanders KM. A case for interstitial cells of Cajal as pacemakers and mediators of neurotransmission in the gastrointestinal tract. Gastroenterology. 1996; 111(2): 492-515, doi: 10.1053/gast.1996.v111.pm8690216, indexed in Pubmed: 8690216.

50. Sanders KM, Ward SM. Kit mutants and gastrointestinal physiology. J Physiol. 2007; 578(Pt 1): 33-42, doi: 10.1113/ jphysiol.2006.122473, indexed in Pubmed: 17095561.

51. Song G, David G, Hirst S, et al. Regional variation in ICC distribution, pacemaking activity and neural responses in the longitudinal muscle of the murine stomach. J Physiol. 2005; 564(Pt 2): 523-540, doi: 10.1113/jphysiol.2004.081067, indexed in Pubmed: 15677686.

52. Strege $P R, O u Y$, Sha $L$, et al. Sodium current in human intestinal interstitial cells of Cajal. Am J Physiol Gastrointest Liver Physiol. 2003; 285(6): G1111-G1121, doi: 10.1152/ ajpgi.00152.2003, indexed in Pubmed: 12893628. 
53. Tang CM, Lee TE, Syed SA, et al. Hedgehog pathway dysregulation contributes to the pathogenesis of human gastrointestinal stromal tumors via GLI-mediated activation of KIT expression. Oncotarget. 2016; 7(48): 78226-78241, doi: 10.18632/oncotarget.12909, indexed in Pubmed: 27793025.

54. Taxi J. [On the existence of ciliated neurons in the sympathetic ganglia of certain vertebrates]. C R Seances Soc Biol Fil. 1961 (155): 1860-1863, indexed in Pubmed: 13919898.

55. Taxi J. Electron microscope study of the innervation of intestinal smooth muscle, compared to that of some other mammalian smooth muscles]. Arch Biol (Liege). 1964(75): 301-328, indexed in Pubmed: 14276581.

56. Thuneberg L. Interstitial Cells of Cajal: Intestinal Pacemaker Cells? Adv Anat Embryol Cell Biol. 1982, doi: 10.1007/9783-642-68417-3.

57. Thuneberg L. Interstitial cells of Cajal. In: Wood JD (ed.). Handbook of Physiology: The Gastrointestinal System. American Physiological Society, Bethesda, Maryland 1989: 349-386.

58. Torihashi S, Ward SM, Nishikawa S, et al. c-Kit-dependent development of interstitial cells and electrical activity in the murine gastrointestinal tract. Cell Tissue Res. 1995; 280(1): 97-111, doi: 10.1007/BF00304515, indexed in Pubmed: 7538451.

59. Torihashi S, Horisawa M, Watanabe Y. c-Kit immunoreactive interstitial cells in the human gastrointestinal tract. J Auton Nerv Syst. 1999; 75(1): 38-50, doi: 10.1016/ s0165-1838(98)00174-x.

60. Vanderwinden J, Verslijpe M, De La, et al. Distribution of interstitial cells of Cajal in human duodenum and intestine. Neurogastroenterol Motil. 1998; 10: 435.

61. Vanderwinden JM, Liu H, De Laet MH, et al. Study of the interstitial cells of Cajal in infantile hypertrophic pyloric stenosis. Gastroenterology. 1996; 111(2): 279-288, doi: 10.1053/gast.1996.v111.pm8690192, indexed in Pubmed: 8690192.

62. Vannucchi M, De Giorgio R, Faussone-Pellegrini M. NK1 receptor expression in the interstitial cells of Cajal and neurons and tachykinins distribution in rat ileum during development. J Comp Neurol. 1998; 383(2): 153-162, doi: 10.1002/(sici)1096-9861(19970630)383:2<153::aidcne3>3.0.co;2-\#.

63. Wang $X Y$, Paterson $C$, Huizinga JD. Cholinergic and nitrergic innervation of ICC-DMP and ICC-IM in the human small intestine. Neurogastroenterol Motil. 2003; 15(5): 531-543, doi: 10.1046/j.1365-2982.2003.00429.x, indexed in Pubmed: 14507353.

64. Ward SM, Burns AJ, Torihashi S, et al. Mutation of the proto-oncogene c-kit blocks development of interstitial cells and electrical rhythmicity in murine intestine. J Physiol. 1994; 480 (Pt 1): 91-97, doi: 10.1113/jphysiol.1994. sp020343, indexed in Pubmed: 7853230.

65. Ward S, Sanders K. Interstitial cells of Cajal: Primary targets of enteric motor innervation. Anat Rec. 2001; 262(1): 125-135, doi: 10.1002/1097-0185(20010101)262:1<125::aidar1017>3.0.co;2-i.

66. Yin J, Chen JDZ. Roles of interstitial cells of Cajal in regulating gastrointestinal motility: in vitro versus in vivo studies. J Cell Mol Med. 2008; 12(4): 1118-1129, doi: 10.1111/j.1582-4934.2008.00352.x, indexed in Pubmed: 18429936.

67. Young HM, Ciampoli D, Southwell BR, et al. Origin of interstitial cells of Cajal in the mouse intestine. Dev Biol. 1996; 180(1): 97-107, doi: 10.1006/dbio.1996.0287, indexed in Pubmed: 8948577.

68. Zhang SC, Fedoroff S. Cellular localization of stem cell factor and c-Kit receptor in the mouse nervous system. J Neurosci Res. 1997; 47(1): 1-15, doi: 10.1002/(sici)10974547(19970101)47:1<1::aid-jnr1>3.0.co;2-n. 